\title{
WHO BEARS THE BURDEN OF VOLUNTARY EXPORT RESTRAINTS?
}

\author{
Fuhmei Wang*
}

\begin{abstract}
Conventional wisdom believes that voluntary export restraints (VERs) are beneficial for the exporting country but detrimental to the importing country. Based on the benchmark model of Obstfeld and Rogoff, this paper aims to examine this belief and evaluate the welfare effects of VERs on the world economy. Analytical results find that VERs exert expansion effects on the exporting economy temporarily. The conventional view of VERs effects holds only when there is perfect competition on the goods market or when the exporting country is bigger than the importing country. On the whole, VERs deteriorate the overall welfare of the world economy.
\end{abstract}

Keywords: voluntary export restraints, welfare effects, country sizes

JEL Classification: F12; F13; F23

\section{Introduction}

Voluntary export restraint (VER) is a quota on trade imposed by the exporting country. A well-known example is the limitation, enforced by Japan, on auto exports to the Unites States after 1981. Some voluntary export agreements cover more than one country. The most famous multilateral agreement is the Multi-Fiber Arrangement, limiting textile exports from 22 countries until the beginning of 2005. For certain political and legal advantages, a VER has become the preferred instrument of trade policy in recent years. Conventional wisdom believes that a VER is beneficial, relative to the import restriction, for the exporting country but detrimental to the importing country in that what would have been revenue induced from restriction rents becomes benefits appropriated to the former that would otherwise accure to the latter.

Existing literature on VERs has focused on establishing the welfare loss to the importing country arising from the conjunction of an income transfer loss and a distortionary efficiency disadvantage in the importing country. Implicit faith is that the exporting country is likely to receive adequate compensation through the often large rent transfer. On the welfare ground, some researchers indicate that VERs could lead to a welfare improvement in the exporting country (e.g. Ono, 1984; Hariss, 1985; Krishna, 1989; Zhou and Vertinsky, 2002; De Santis, 2003). A good deal of work has investigated

* Department of Economics, National Cheng Kung University, Tainan, 701 Taiwan, R.O.C.

(fmwang@mail.ncku.edu.tw). The author is thankful to the National Science Council in Taiwan for providing the foreign research scholarship, 99-2918-I-006-014 and to the Fulbright Foundation for the 2009-2010 research awards. The usual disclaimer applies. 
effects of VERs on strategic variables in imperfectly competitive market structure from country experiences (e.g. Anderson, 1985; Aw, 1992; Flam, 1994; El-Agraa, 1995; Berry et al., 1999). Recently, most of the literature suggests that the degree of product differentiation or the nature of competition has an enforcement mechanism within itself to the successful attainment of VERs (Moore and Suranovic, 1993; Chao and Yu, 1996; Bouët, 2001; Okawa, 2004; Moore, 2005; Demidova and Rodrigues-Clare, 2009). The home government persuades the exporting firms to allow smaller exportation of home products; the exporting country is eventually obliged to bear the burden of contracting the market. These well-known studies nevertheless are based on trade theory, being different from literature of "new open macroeconomics" perspectives.

Imperfect competition has been important in macroeconomics since the early 1980s. Obstfeld and Rogoff (1995) develop an important model on the international welfare spillovers through a global framework and provide a well-grounded welfare criterion to evaluate public policies. Substantial literature has extended the Obstfeld and Rogoff model in a number of directions. The literature focused on the investigation of exchange rate behavior. As far as trade protection is concerned, Fender and Yip (2000) develop their analysis to tariff effects. However, this extension does not quantify such protection effects, which are interesting features in commercial policies.

This research applies Obstfeld and Rogoff's framework to the commercial policy of VERs, generating various policy results. Analytical results suggest that VERs only exert transitory expansion effects on the exporting country. In the long run, the exporting country experiences reduction in output and consumption, a deficit of the current account, and deterioration of the terms of trade. On the whole, VERs harm the welfare status of the world. In the long run, VERs cannot affect either macroeconomics or welfare of the importing (foreign) country, a result which is different from that of De Santis (2003).

This study examines two issues: first, in the presence of monopolistic competition, the macroeconomic responses to a VER, and second the sticky-price multiplier compared to the corresponding long-run multiplier. This paper contributes to existing literature in the following aspects.

(i) This is the first structure based on international parameterization studies, to our knowledge, to investigate the spillover and welfare effects of VERs.

(ii) Sticky output prices provide a new mechanism for the exchange rate actually being volatile on impact (e.g. Obstfeld and Rogoff, 1995).

(iii) The analytical model elaborates welfare investigation for the world economy as a whole, where the relative efficiency of VERs is analyzed in consumer surplus literature (e.g. Dei, 1985).

The remainder of this article is organized as follows: Section 2 establishes the theoretical model. Section 3 presents the VERs effects through theoretical and numerical investigations. Section 4 outlines the welfare evaluations. Section 5 discusses and concludes.

\section{The Theoretical Model}

Consider a two-country world with differentiated (non-storable) goods and monopolistic competition. The voluntary export restraint is imposed by the exporting 
country through an ad-valorem export tax, which leads to an increase in the world price, as explained in Gandolfo (1998).

Briefly, the world is composed of two sets of agents: households, producing and consuming, with governments. Two assets exist: domestic and foreign currencies. In the long term, current accounts are balanced. The problems faced by each firm and consumer as well as the government are presented in the following.

\section{Firms and Consumers}

Households, are indexed by $j \in[0,1]$ and distributed uniformly over $[0, n]$ and $(n, 1]$ for domestic and foreign firms (consumers) respectively. The index presents not only the production share in the world goods market but also the measure of relative size of the home economy. The home country size increase in $n$. Household $j$ supplies labour of variety $j$ as well as derives utility from consumption, real money balances, and output whose only input is work effort. In discrete time, the utility function of a domestic resident is: $U$

$$
U_{t}=\sum_{k=t}^{\infty} \delta^{k-t}\left[\alpha \ln C_{k}+(1-\alpha) \ln \left(M_{k} / P_{k}\right)-\mu y_{k}^{2} / 2\right]
$$

Parameter $\delta$ presents the discounting factor. The utility function of the foreign household is defined analogously. Variables pertaining to the foreign country will be denoted by an asterisk throughout. The first term, consumption index $C$, in the utility function can be expressed as:

$$
C=\left[\int_{0}^{1} c(j)^{\sigma} d j\right]^{\frac{1}{\sigma}} \quad 0<\sigma<1
$$

In equation (2), $c(j)$ denotes the consumption of household $j$, and $C$ is a $C E S$ (constant elasticity of substitution) function of $c(j)_{s}$. Foreign households have the analogous consumption index. Parameter $\sigma$ presents a preference parameter and lies in the open interval $(0,1)$, which makes one equilibrium certain. The degree of substitutability between different variety goods increases in $\sigma$. The elasticity of substitution between goods is $1 /(1-\sigma)$. When $\sigma$ equals one, the goods market becomes perfect competition. All agents have the same tastes for varieties.

The second term in utility is the effect of real money balance on utility. Nominal money balance, $M$, is deflated by the nominal price index, $P$, which is associated with consumption index. An exported good $j \in[\mathrm{k}, \mathrm{n}]$ for the home country is subject to a VER with the rate of the (ad-valorem) export tax, $\gamma$. The remainder, indexed by $j \in[0, k)$, are not subject to VERs. A VER limiting supplies in the importing country has the effect of raising the price there in much the same way as an import quota, albeit under the latter the rents are captured by the importers, under the former they are captured by the exporters (Gandolfo, 1998, pp.206-207). Being symmetrical among households, the price index of the home country is then presented as:

$$
P=\left[\int_{0}^{1} p(j)^{1 / \theta} d j\right]^{\theta}=\left\{\int_{0}^{k} p(j)^{1 / \theta} d j+\int_{k}^{n}[p(j)(1+\gamma)]^{1 / \theta} d j+\int_{n}^{1}\left[E p^{*}(j) d j\right]^{1 / \theta}\right\}^{\theta}
$$

The corresponding price index of a foreign country is given by

$$
P^{*}=\left[\int_{0}^{1} p^{*}(j)^{1 / \theta} d j\right]^{\theta}
$$


Define $\theta$ as $(\sigma-1) / \sigma$. In equations (3) and (4), $p(j)$ and $p^{*}(j)$ denote the domestic and foreign nominal output prices of variety $j$, respectively. Because VERs do not change the elasticity of demand faced by producers, free movement of goods implies that the law of one price holds for all producer prices:

$$
p(j)=E p^{*}(j)
$$

However, the law of one price will not hold for consumer prices of VERs restricted goods. Exchange rate, $E$, is defined as the price of one unit of foreign currency in terms of domestic currencies. To investigate the budgeting procedure for the consumption of variety $j$ and derive its demand function, assume that all goods have unitary income elasticity. The demand function for individual variety of domestic households is:

$$
c_{t}(j)=C_{t}\left[P_{t} / p_{t}(j)\right]^{1 /(1-\sigma)}
$$

The demand functions of foreign households are:

$$
\begin{gathered}
c_{t}^{*}(j)=C^{*}{ }_{t}\left[P_{t}^{*} / p_{t}{ }^{*}(j)\right]^{1 /(1-\sigma)} \text { for } \mathrm{j} \in[0, \mathrm{k}) \text { and } \mathrm{j} \in(\mathrm{n}, 1] \\
c_{t}{ }^{*}(j)=C^{*}{ }_{t}\left\{P_{t}^{*} /\left[p_{t}(j)(1+\gamma) / E_{t}\right]\right\}^{1 /(1-\sigma)} \text { for } \mathrm{j} \in[\mathrm{k}, \mathrm{n}]
\end{gathered}
$$

Each household takes the price index as given, inputs labor to produce its own variety of products, and chooses $p_{t}(j)$ to maximize its output revenue. The maximization problems are subject to budget constraints. In each period, domestic households' budget constraint is:

$$
M_{t}=p_{t} y_{t}+M_{t-1}-P_{t} C_{t}-P_{t} T_{t}+P_{t} R_{t}
$$

In equation (8), $T_{t}$ is the real tax paid to domestic government and $R_{t}$ is the export tax revenue, being distributed to consumers in a lump-sum fashion. Private asset accumulation equals product and export duty revenue minus the consumption expenditure and taxation paid to governments. Foreign households have similar budget constraints except without export duty revenue.

\section{The Government}

Governments have identical preferences to those of households. Domestic government's demand for the product of variety $j$ is:

$$
g_{t}(j)=G_{t}\left[p_{t}(j) / P_{t}\right]^{1 /(1-\sigma)}
$$

The foreign government has the same demand function. Domestic government distributes the export tax revenue to the consumers as well as finances government expenditure through taxes, and the constraint is (in real terms):

$$
T_{t}=G_{t}
$$

Foreign government finances its expenditure through taxation from foreign households, and the constraint is: 


$$
T_{t}^{*}=G_{t}^{*}
$$

Combining the budget constraints of governments with those of households, after consuming and financing the government builds up per capita real money holdings or trade balance (deficit):

$$
\left(m_{t}-m_{t-1}\right)=\left(p_{t} / P_{t}\right) y_{t}(j)-G_{t}-C_{t}+R_{t}
$$

and

$$
\left(m_{t}^{*}-m_{t-1}^{*}\right)=\left(p_{t}^{*} / P_{t}^{*}\right) y_{t}^{*}(j)-G_{t}^{*}-C_{t}^{*}
$$

\section{The World Demand}

Adopting population weights and adding up private as well as government demands, the world demand curve for domestic product $j$ is:

$$
n c_{t}(j)+(1-n) c_{t}^{*}(j)+n g_{t}(j)+(1-n) g_{t}^{*}(j)=y_{t}(j)
$$

Using equations (6), (7) and (9), the world demand curve for domestic outputs is:

$$
y_{t}(j)=\left(p_{t} / P_{t}\right)^{1 / \sigma-1}\left(C_{t}^{W}+G_{t}^{W}\right)+(1-n)(n-k)\left[(1+\gamma)^{1 /(\sigma-1)}-1\right]\left(p_{t}^{*} / P_{t}^{*}\right)^{1 /(\sigma-1)} C^{*}
$$

The world demand curve for foreign goods is

$$
y_{t}^{*}(j)=\left(p_{t}^{*} / P_{t}^{*}\right)^{1 /(\sigma-1)}\left(C_{t}^{W}+G_{t}^{W}\right)
$$

Equations (15) and (16) have made use of the definitions of world private and government demand; that is

$$
\begin{aligned}
C_{t}^{W} & =n C_{t}+(1-n) C_{t}^{*} \\
G_{t}^{W} & =n G_{t}+(1-n) G_{t}^{*}
\end{aligned}
$$

The solution for relevant optimization conditions yields the steady state values of per capita consumption:

and

$$
\bar{C}=(\bar{p} / \bar{P}) \bar{y}-\bar{G}+\bar{R}
$$

$$
\bar{C}^{*}=\left(\bar{p}^{*} / \bar{P}^{*}\right) \bar{y}^{*}-\bar{G}^{*}
$$

The time subscripts of steady states have been dropped, and overbars stand for the steady state values. Given the assumption that real government expenditure in the initial steady state equals zero, the initial steady state values with subscript zero of domestic and foreign outputs and those of real money balances are: $\bar{y}_{0}=\bar{y}_{0}^{*}=(\alpha \sigma / \mu)^{1 / 2}$, and $\bar{m}_{0}=\bar{m}_{0}^{*}=(1-\alpha) \bar{y}_{0} / \alpha(1-\delta)$. This completes the explanations of the theoretical model. 


\section{VERs Effects}

This section investigates the effects of imposing voluntary export restraints both in short run and long run.

\section{Short-Run Effects}

Through log-linearization and direct solving techniques, with the assumption that individuals enter at period $t$, the changes of relevant variables are presented as

$$
\begin{aligned}
& \hat{y}=(1-n)(n-k) d \gamma+[(1+n) / 2] d G+[(1-n) / 2] d G^{*} \\
& \hat{y}^{*}=-n(n-k) d \gamma+(n / 2) d G+[(2-n) / 2] d G^{*} \\
& \hat{C}=d m=\left[\left(\sigma^{2}-2 \sigma-1\right)(1-n)(n-k) / \sigma-1\right] d \gamma+\left[(1-n)(\sigma-2)\left(d G-d G^{*}\right) / 2\right] \\
& \hat{C}^{*}=d m^{*}=\left[-n\left(\sigma^{2}-2 \sigma-1\right)(n-k) / \sigma-1\right] d \gamma-\left[n(\sigma-2)\left(d G-d G^{*}\right) / 2\right] \\
& \hat{C}^{W}=0 \\
& \hat{P}=(2-n-\sigma+\sigma n)(n-k) d \gamma+[(1-\sigma)(1-n) / 2]\left(d G-d G^{*}\right) \\
& \hat{P}^{*}=-n(1-\sigma)(n-k) d \gamma-[n(1-\sigma) / 2]\left(d G-d G^{*}\right) \\
& \hat{E}=(1-\sigma)(n-k) d \gamma+[(1-\sigma) / 2]\left(d G-d G^{*}\right)
\end{aligned}
$$

These macroeconomic effects suggest that, without government spending, $d G=d G^{*}=0$, a VER raises consumption, output and improves the current account in the home country (the exporter) in the short run. In contrast, a VER reduces output and consumption and deteriorates the current account in the foreign country (the importer). Parameterization examples quantify the magnitude effects. The simulation structure is composed of equations (13), (14), (16), (17) and their relevant optimizing conditions as well as the corresponding descriptions of a foreign economy. In reality, domestic economy is small compared with the rest of the world. Domestic country size, $n$, is specified as 0.4 . The export tax rate, $\gamma$, and the ratio of goods not subject to VERs, $k$, are respectively set at 0.1 and 0.2 . The discounting factor of 0.8 is adapted from Jones et al. (1993). Productivity parameter, $\mu$ is chosen at 1.6. This value does not change the results, as $\mu$ only affects the initial values of domestic and foreign outputs among the variables quantified below. The share of utility deriving from consumption is set at 0.5 . The goods market is neither perfect competition nor monopoly; the degree of substitutability between different variety goods is set at 0.8 . Using these parameter settings, the steady state values of foreign real interest rate, domestic output, foreign output, domestic real balances, and foreign real balances are in order calibrated as $0.25,0.5,0.5,2.5$, and 2.5 as Table 1 presents.

On impact, as Table 2 and Figure 1 indicate, the home country produces more due to the expectation of the future increase in output prices. The higher production leads to an increase in consumption. The home country runs current account surplus in that the real output increases much more than consumption does. The exchange rate also depreciates. With sticky output prices, the changes in consumption price indexes only 
result from the variation of exchange rates, which in turn results in a higher home consumption price index but a lower foreign price. With constant world resources, production and consumption decrease in the importing country in that home firms devote considerable resources to producing differentiated goods. In this case, a foreign current account deficit occurs. The magnitude effects of VERs in both economies increase in the ad-valorem rates of such export restraints.

Table 1

\section{Key Parameter Values at Initial Steady-state Equilibrium}

\begin{tabular}{|l|l|}
\hline Consumption share in utility $\alpha$ & 0.5 \\
\hline Productivity factor $\mu$ & 1.6 \\
\hline Discounting factor $\delta$ & 0.8 \\
\hline Substitute elasticity of demand $\sigma$ & 0.8 \\
\hline Foreign real interest rate $\gamma^{*}=(1-\delta) / \delta$ & 0.25 \\
\hline Domestic output $y_{0}=(\alpha \sigma / \mu)^{1 / 2}$ & 0.5 \\
\hline Foreign output $y_{0}^{*}=(\alpha \sigma / \mu)^{1 / 2}$ & 0.5 \\
\hline Domestic real balances $m_{0}=(1-\alpha) y_{0} / \alpha(1-\delta)$ & 2.5 \\
\hline Foreign real balances $m_{0}^{*}=(1-\alpha) y_{0}^{*} / \alpha(1-\delta)$ & 2.5 \\
\hline
\end{tabular}

Table 2

Impact Effects of a VER Imposed $(\sigma=0.8)$

\begin{tabular}{|l|c|c|c|c|c|c|c|c|c|c|c|}
\hline Period & $\boldsymbol{\gamma}$ & $\boldsymbol{n}$ & $\boldsymbol{k}$ & $\boldsymbol{m}$ & $\boldsymbol{m}^{*}$ & $\boldsymbol{C}^{w}$ & $\boldsymbol{y}$ & $\boldsymbol{y}^{*}$ & $\boldsymbol{C}$ & $\boldsymbol{C}^{*}$ & $\boldsymbol{E}$ \\
\hline $\boldsymbol{t}-\mathbf{1}$ & 0 & $\begin{array}{r}0.1 \sim \\
0.9\end{array}$ & 0 & 2.5 & 2.5 & 0.5 & 0.5 & 0.5 & 0.5 & 0.5 & 1 \\
\hline $\boldsymbol{t}$ & 0.1 & 0.4 & 0.2 & 2.707 & 2.382 & 0.5 & 0.812 & 0.322 & 0.541 & 0.476 & 1.18 \\
\hline $\boldsymbol{t}$ & 0.5 & 0.4 & 0.2 & 3.535 & 1.91 & 0.5 & 2.062 & 0 & 0.707 & 0.382 & 1.9 \\
\hline $\boldsymbol{t}$ & 1 & 0.4 & 0.2 & 4.57 & 1.32 & 0.5 & 3.624 & 0 & 0.914 & 0.264 & 2.8 \\
\hline
\end{tabular}

Figure 1(a)

Impact Effects of a VER on the Domestic Economy (the exporting country)

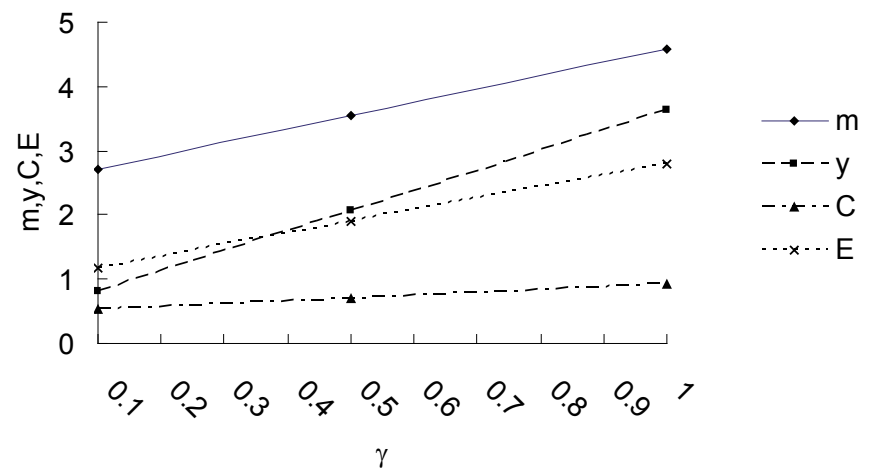


Figure 1(b)

Impact Effects of a VER on the Foreign Economy (the importing country)

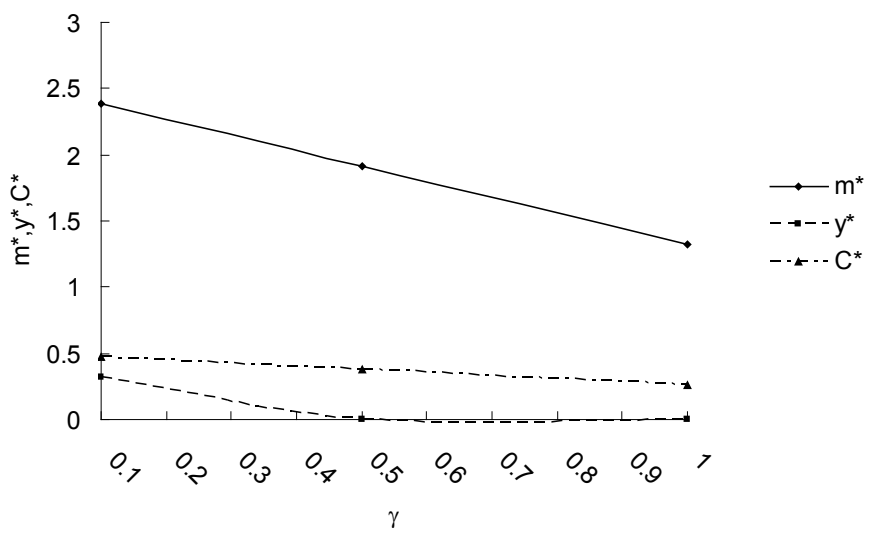

Table 3 and Figure 2 present how goods being subject to VERs, $k$, affect the world economy. The more the goods are subject to VERs, the more likely it is to see fewer positive effects on home output, consumption and asset accumulation, and fewer harmful effects on the respective variables in the importing country. With more differentiated goods, being subject to VERs in the product group, home firms adjust production expansion via exports for declining the market share to a negotiated rate. This situation would consequently reduce the determintal effects of VERs on the macroeconomy of the importing country.

Table 3

Dependence of Impact Effects on $k$ in a VER $(\sigma=0.8)$

\begin{tabular}{|l|c|c|c|c|c|c|c|c|c|c|c|}
\hline Period & $\boldsymbol{\gamma}$ & $\boldsymbol{n}$ & $\boldsymbol{K}$ & $\boldsymbol{m}$ & $\boldsymbol{m}^{*}$ & $\boldsymbol{C}^{w}$ & $\boldsymbol{y}$ & $\boldsymbol{y}^{*}$ & $\boldsymbol{C}$ & $\boldsymbol{C}^{*}$ & $\boldsymbol{E}$ \\
\hline $\boldsymbol{t}-\mathbf{1}$ & 0 & $\begin{array}{r}0.1 \sim \\
0.9\end{array}$ & 0 & 2.5 & 2.5 & 0.5 & 0.5 & 0.5 & 0.5 & 0.5 & 1 \\
\hline $\boldsymbol{t}$ & 0.1 & 0.4 & 0.1 & 2.81 & 2.323 & 0.5 & 0.969 & 0.234 & 0.562 & 0.465 & 1.27 \\
\hline $\boldsymbol{t}$ & 0.1 & 0.4 & 0.2 & 2.707 & 2.382 & 0.5 & 0.812 & 0.322 & 0.541 & 0.476 & 1.18 \\
\hline $\boldsymbol{t}$ & 0.1 & 0.4 & 0.3 & 2.604 & 2.441 & 0.5 & 0.656 & 0.411 & 0.521 & 0.488 & 1.09 \\
\hline
\end{tabular}

Figure 2(a)

Dependence of VER Effects on Restricted Varieties on the Domestic Economy (the exporting country)

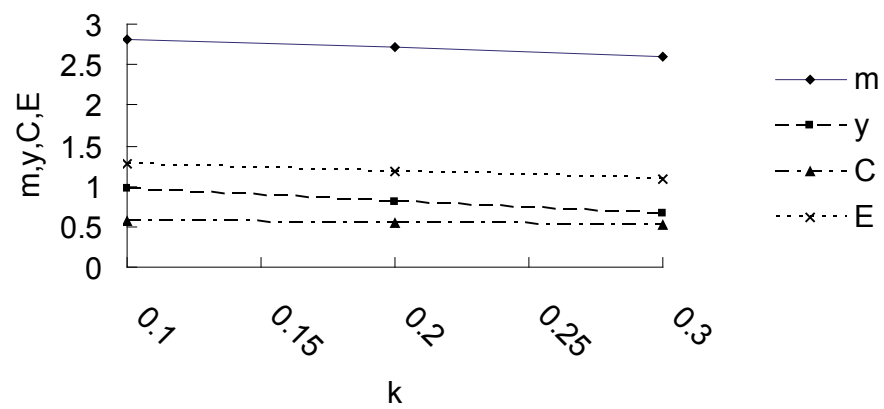


Figure 2(b)

Dependence of VER Effects on Restricted Varieties on the Foreign Economy (the importing country)

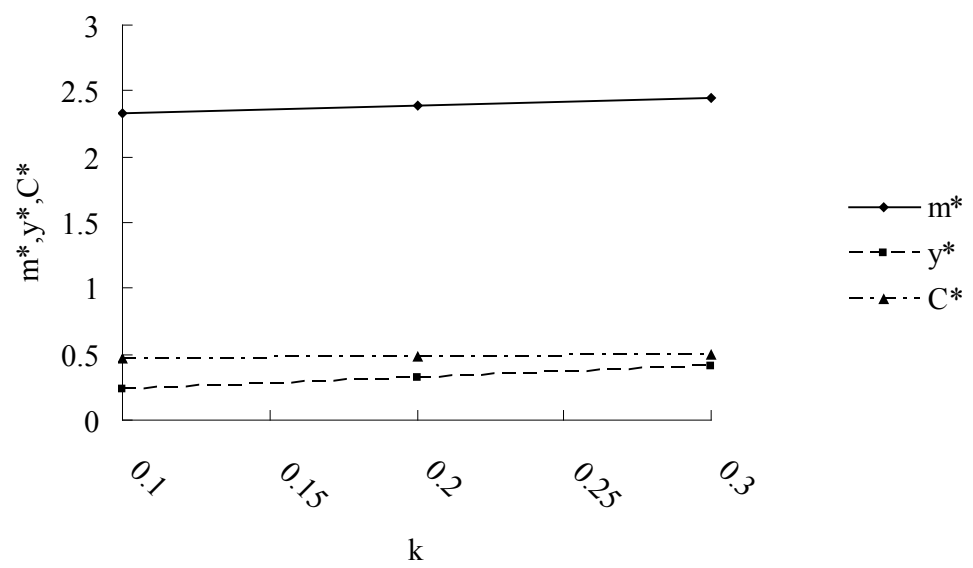

The dependence of VERs effects on country sizes is presented in Table 4 and Figure 4. This reliance is not monotonic. We find that the relationship between home country sizes and how the export restraints affect the output, consumption, and the trade balance in the exporting country is positive, yet there is some form of weak inverse U shape. A VER acts like a premium, which is proportionately higher on high-priced goods than on low-priced goods. Producers have an incentive to upgrade from lowerto-higher-quality products within the product category. Quality upgrading shifts world demand outward, which in turn stimulates output expansion and improves the current account. These facts can be seen when the United States required a four-year VERs in mid-1977 on the South Korea and Taiwan's nonrubber footwear exports. Nevertheless, South Korea and Taiwan continued to expand their market shares during this period of restriction. Since then China has overtaken them both. Referring to the importing country, the current account worsens and outputs continue to decrease, which leads to decreases in consumption and imports from abroad. The expansionary effects of VERs on the exporting economy then slow down.

Table 4

Dependence of Impact Effects on $n$ in a VER $(\sigma=0.8)$

\begin{tabular}{|l|c|c|c|c|c|c|c|c|c|c|c|}
\hline Period & $\boldsymbol{\gamma}$ & $\boldsymbol{N}$ & $\boldsymbol{K}$ & $\boldsymbol{m}$ & $\boldsymbol{m}^{*}$ & $\boldsymbol{C}^{\boldsymbol{w}}$ & $\boldsymbol{y}$ & $\boldsymbol{y}^{*}$ & $\boldsymbol{C}$ & $\boldsymbol{C}^{*}$ & $\boldsymbol{E}$ \\
\hline $\mathbf{t}-\mathbf{1}$ & 0 & $\begin{array}{l}0.1 \sim \\
0.9\end{array}$ & 0 & 2.5 & 2.5 & 0.5 & 0.5 & 0.5 & 0.5 & 0.5 & 1 \\
\hline $\mathbf{t}$ & 0.1 & 0.3 & 0.2 & 2.618 & 2.456 & 0.5 & 0.678 & 0.433 & 0.524 & 0.491 & 1.09 \\
\hline $\mathbf{t}$ & 0.1 & 0.6 & 0.2 & 2.796 & 2.146 & 0.5 & 0.947 & 0 & 0.559 & 0.429 & 1.36 \\
\hline $\mathbf{t}$ & 0.1 & 0.9 & 0.2 & 2.708 & 1.571 & 0.5 & 0.816 & 0 & 0.542 & 0.314 & 1.63 \\
\hline
\end{tabular}


Figure 3(a)

Dependence of VER Effects on Home Country Sizes on the Domestic Economy (the exporting country)

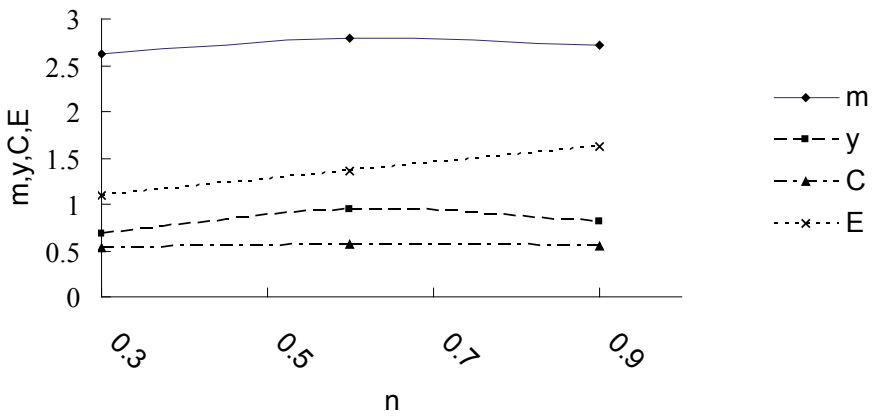

Figure 3(b)

Dependence of VER Effects on Home Country Sizes on the Foreign Economy (the importing country)

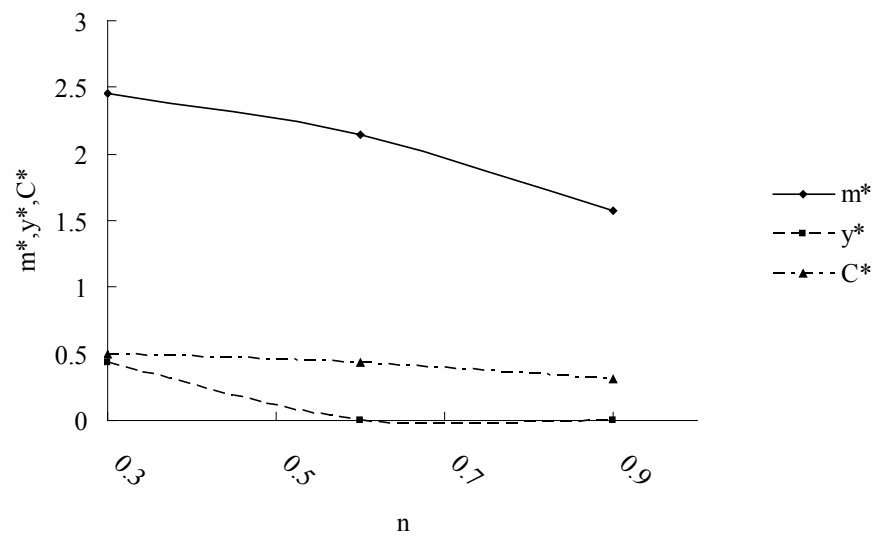

Imperfect competition is due to various forms of increasing returns to scale and product differentiations. Voluntary export restraints stimulate exporters' outputs as mentioned above, yet firms often devote considerable resources to differentiation of their products from those of their competitors and the allocation inefficiency might exist. If the goods market is imperfectly competitive, a firm may be operating on a declining part of its average-cost curve. Therefore, increasing production via exports would reduce the average cost, which would consequently enhance profits. The advantage of economies of scale increases in the degrees of goods substitution. Table 5 and Figure 4 present how the degree of goods substitution affects macroeconomic effects of VERs. The magnitude of expansion (contraction) impact effects of VERs on the exporting (importing) country increases in goods market competition. 
Table 5

Dependence of Impact Effects on $\sigma$ in a VER

\begin{tabular}{|l|c|c|c|c|c|c|c|c|c|c|c|c|}
\hline Period & $\boldsymbol{\sigma}$ & $\boldsymbol{\gamma}$ & $\boldsymbol{n}$ & $\boldsymbol{k}$ & $\boldsymbol{m}$ & $\boldsymbol{m}^{*}$ & $\boldsymbol{C}^{\boldsymbol{w}}$ & $\boldsymbol{y}$ & $\boldsymbol{y}^{*}$ & $\boldsymbol{C}$ & $\boldsymbol{C}^{*}$ & $\boldsymbol{E}$ \\
\hline $\mathbf{t}-\mathbf{1}$ & $0 \sim 1$ & 0 & $\begin{array}{l}0.1 \sim \\
0.9\end{array}$ & 0 & 2.5 & 2.5 & 0.5 & 0.5 & 0.5 & 0.5 & 0.5 & 1 \\
\hline $\mathbf{t}$ & 0 & 0.1 & 0.4 & 0.2 & 2.527 & 2.5 & 0.5 & 0.548 & 0.498 & 0.505 & 0.5 & 1.02 \\
\hline $\mathbf{t}$ & 0.3 & 0.1 & 0.4 & 0.2 & 2.531 & 2.499 & 0.5 & 0.558 & 0.492 & 0.506 & 0.5 & 1.03 \\
\hline $\mathbf{t}$ & 0.6 & 0.1 & 0.4 & 0.2 & 2.557 & 2.482 & 0.5 & $0.6-2$ & 0.462 & 0.511 & 0.496 & 1.08 \\
\hline $\mathbf{t}$ & 0.8 & 0.1 & 0.4 & 0.2 & 2.707 & 2.382 & 0.5 & 0.812 & 0.322 & 0.541 & 0.476 & 1.18 \\
\hline $\mathbf{t}$ & 0.95 & 0.1 & 0.4 & 0.2 & 6.232 & 0.032 & 0.5 & 5.222 & 0 & 1.246 & 0.006 & 1.78 \\
\hline
\end{tabular}

Figure 4(a)

Dependence of VER Effects on Degrees of Goods Substitution on the Domestic Economy (the exporting country)

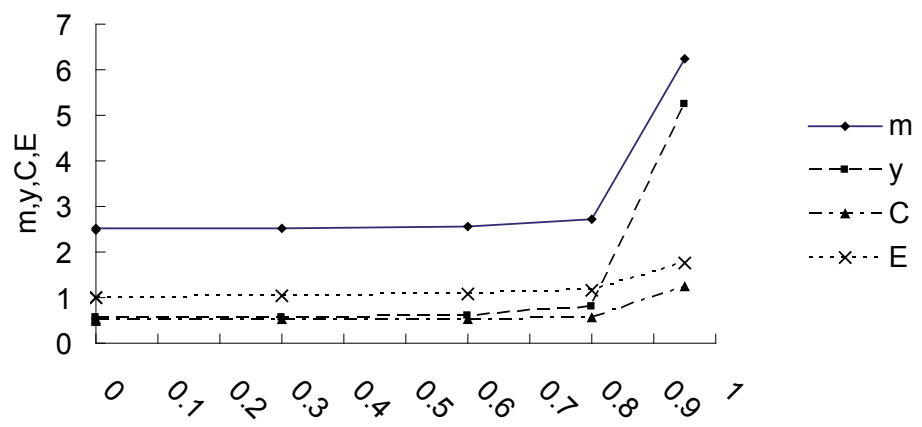

Figure 4(b)

Dependence of VER Effects on Degrees of Goods Substitution on the Foreign Economy (the importing country)

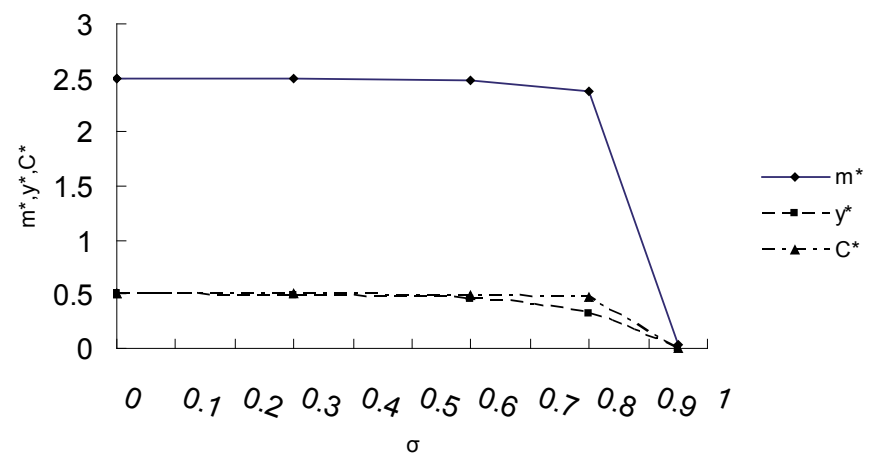

The following proposition summarizes the impact effects of VERs:

Proposition 1: With imperfect competition, on impact, a VER raises consumption, output and current account surplus of the exporting country (home country) but 
reduces the values of respective variables of the importing country (foreign country). The expansion impacts on the exporting economy increase in the degree of substitution between goods but decrease in the varieties being subject to VERs.

\section{Long-Run Effects}

Define the steady state change as the percentage change in the steady-state value, for example, $\hat{\bar{y}}=d \bar{y} / \bar{y}_{0}$. Utilizing the condition of the demand for real balances to be equal to consumption, equations (14)-(20) then can solve nine unknowns: $\hat{\bar{y}}, \hat{\bar{y}}^{*}, \hat{\bar{C}}$, $\hat{\bar{C}}^{*}, d \bar{m}, d \bar{m}^{*},(\hat{\bar{p}}-\hat{\bar{P}}),\left(\hat{\bar{p}}^{*}-\hat{\bar{P}}^{*}\right)$ and $\hat{\bar{C}}^{W}$. The solutions for relevant changes are:

$$
\begin{aligned}
& \hat{\bar{y}}=[(\sigma-1)(1-n)(n-k) / 2] d \gamma+[(1+2 n) / 2] d \bar{G}+[(1-2 n) / 2] d \bar{G}^{*} \\
& \hat{\bar{y}}^{*}=n d \bar{G}+(1-n) d \bar{G}^{*} \\
& \hat{\bar{C}}=d \bar{m}=(1-n)(n-k)\left(\sigma^{2}-3\right) d \gamma / 2+[n+(1-n)(\sigma-2)] d \bar{G} / 2+(1-n) d \bar{G}^{*} \\
& \hat{\bar{C}}^{*}=d \bar{m}^{*}=(1-\sigma+2 n)\left(d \bar{G}-d \bar{G}^{*}\right) / 2 \\
& \hat{\bar{p}}(h)-\hat{\bar{P}}=\left[(1-n)(n-k)\left(\sigma^{2}-2 \sigma-1\right)\right] d \gamma / 2+[(n-1)(1-\sigma) d \bar{G}] / 2+\left[(1-\sigma) d \bar{G}^{*}\right] / 2 \\
& \hat{\bar{p}}^{*}(f)-\hat{\bar{P}}^{*}=\left[(1-\sigma)\left(d \bar{G}-d \bar{G}^{*}\right)\right] / 2 \\
& \hat{\bar{E}}=-(n-k) d \gamma
\end{aligned}
$$

Equations (29)-(35) suggest that, with imperfect competition and without government spendings, imposing VERs reduces output, consumption, and real balances as well as deteriorates the terms of trade of the home economy (exporting country) but cannot change anything in the foreign economy (importing country) in the long run. The exporting country is obliged to limit its market-share VERs by imposing export duties. The world demand decreases, in turn leading to decreases in home output, consumption, and real money balances in the long run. The smaller the $\sigma$, (less competition in the goods market), the more vulnerable the home economy imposing VERs. Furthermore, the negative effects increase with the country size of home country, $n$, but decrease with the VERs imposed goods. Table 6 reports the quantified long-run effects of VERs. Comparing to the values of initial steady state, with VERs, domestic output decreases by 0.002 , consumption decreases by 0.001 , current account worsens by 0.003 , and the terms of trade deteriorates by 0.003 in the long run. Though the magnitude effects are numerically small, simulation examples point out that VERs exert positive macroeconomic effect on the exporting country temporarily and enhance the validity of the revealed analytical findings. 
Table 6

Long-run Effect of a VER

\begin{tabular}{|l|l|l|l|l|l|l|l|l|l|l|l|c|}
\hline Period & $\boldsymbol{\Gamma}$ & $\boldsymbol{n}$ & $\boldsymbol{k}$ & $\boldsymbol{m}$ & $\boldsymbol{m}^{*}$ & $\boldsymbol{C}^{\boldsymbol{w}}$ & $\boldsymbol{y}$ & $\boldsymbol{y}^{*}$ & $\boldsymbol{C}$ & $\boldsymbol{C}^{*}$ & $\boldsymbol{p} / \boldsymbol{P}$ & $\boldsymbol{p}^{*} / \boldsymbol{P}^{*}$ \\
\hline $\mathbf{t}-\mathbf{1}$ & 0 & $\begin{array}{l}0.1 \sim \\
0.9\end{array}$ & 0 & 2.5 & 2.5 & 0.5 & 0.5 & 0.5 & 0.5 & 0.5 & 0.5 & 1 \\
\hline $\mathbf{t}$ & 0.1 & 0.4 & 0.2 & 2.707 & 2.382 & 0.5 & 0.812 & 0.322 & 0.35 & 0.5167 & 0.35 & 1.41 \\
\hline $\mathbf{t + 1}$ & 0.1 & 0.4 & 0.2 & 2.497 & 2.5 & 0.5 & 0.498 & 0.5 & 0.499 & 0.5 & 0.997 & 1 \\
\hline
\end{tabular}

Constant world resources and world money supply ensure that $n d \bar{m}+(1-n) d \bar{m} *=0$, which in turn implies that inflation rates in both countries are zero $\left(\pi=\pi^{*}=0\right)$. Then the steady state values of consumption prices do not change. The relative price changes come from the output price and exchange rate variation. In the long run, domestic currency appreciates. Comparing equation (28) to equation (35), on impact, exchange rate overshooting exists. Without VERs, as shown by Obstfeld and Rogoff (1995) (e.g. pp. 640 and pp. 644), the exchange rate jumps immediately to its long-run level and the condition, $\hat{E}=\hat{\bar{E}}$, holds. In their model, preset prices actually reduce exchange rate volatility. In this study, on impact, the more monopoly power producers have, the bigger the size of the home country, or the less VERs set goods are, the exchange rate volatility is bigger. This is demonstrated in the limitations placed on auto exports to the United States (foreign country) enforced by Japan (home country) after 1981. When a VER was imposed on the domestic-currency prices of differentiated goods, Japanese cars, the demand for domestic goods fell and domestic currency tended to depreciate so that domestic goods could still sell well. On impact, the role of exchange rates could be regarded as a substitute for price flexibility in fostering relative price adjustment. In the long run though, Japanese and U.S. cars are clearly not perfect substitutes as Japanese firms, to some extent, respond to VERs by upgrading their quality and selling cars with more features, the price of Japanese cars in the United States increases. VERs reduces the foreign demand for VERs set goods. The competitiveness of the foreign country increases. The appreciation of the exchange rate can induce an increase in the specific level of restraints. When the substitution degree between goods is zero or the economy approaches monopoly, the magnitude of exchange rate appreciation in the long run and that of exchange rate depreciation with sticky price should be equailized.

The following proposition summarizes the effects of VERs in the long run.

Proposition 2: With imperfect competition, VERs are vulnerable to the exporting country (home economy) in the long run. VERs reduce output, consumption, and real balances as well as deteriorate the terms of trade of the exporting country but cannot change anything in the importing country (foreign economy).

\section{Welfare Evaluations}

From the utility function described in equation (1), the change of welfare, resulting from exogenous shocks, is divided into real and monetary parts. That is, $d U=d U^{R}+d U^{m}$. The impact and long-run effects of VERs on the utility function of domestic economy are composed of real, $d U^{R}=\alpha(\hat{C}-\sigma \hat{y})$, as well as monetary terms, $d U^{m}=(1-\alpha) d m$. Total effects of voluntary export restraints on domestic (foreign) welfare are the sum 
of permanent and temporary effects in real terms as well as those in monetary terms.

Substituting the relevant numerical values from Tables 2 and 6 into the real terms of domestic (foreign) utility function, equation (1), given $d \bar{G}=0$ and $d \bar{G}^{*}=0$, yields that on impact, a VER imposed by an exporting country will decrease per capita domestic utility by 0.288 but increase per capita foreign utility by 0.093 . In monetary terms, it increases per capita domestic utility by 0.04 but decreases per capita foreign utility by 0.024 and hence, adding population weights, it decreases the global real terms of welfare by 0.0594 but increases monetary terms of welfare by 0.0016 . In the long run, incorporating population weights with domestic country size 0.4 and foreign country size 0.6 , the magnitude of increases in global real terms of welfare, are equal to that of decreases in global money terms of welfare, 0.000192 as shown in Table 7.

Table 7

Welfare Effects of VERs

\begin{tabular}{|l|c|c|r|r|r|c|}
\hline VERs & \multicolumn{2}{|c|}{$\begin{array}{c}\text { Domestic } \\
\text { (per capita) }\end{array}$} & \multicolumn{2}{c|}{$\begin{array}{c}\text { Foreign } \\
\text { (per capita) }\end{array}$} & \multicolumn{2}{c|}{$\begin{array}{c}\text { Global } \\
\text { (adding population weights) }\end{array}$} \\
\hline Effects & Real terms & $\begin{array}{c}\text { Monetary } \\
\text { terms }\end{array}$ & $\begin{array}{c}\text { Real } \\
\text { terms }\end{array}$ & $\begin{array}{c}\text { Monetary } \\
\text { terms }\end{array}$ & $\begin{array}{c}\text { Real } \\
\text { terms }\end{array}$ & Monetary terms \\
\hline On impact & -0.288 & 0.040 & 0.093 & -0.024 & -0.0594 & 0.0016 \\
\hline Long run & 0.00048 & -0.00048 & 0 & 0 & 0.000192 & -0.000192 \\
\hline
\end{tabular}

A VER always reduces world welfare and can hence never be a first-best policy. From conventional wisdom, VERs would be beneficial, relative to import restrictions, for the exporting country and detrimental to the importing country. The above analysis reveals that the traditional recognition is more likely to hold temporarily if goods market approaches perfect competition and the exporting country is bigger than the importing country. Based on the similar model, Fender and Yip (2000) (e.g. pp. 646) present relevant results that, in the steady state, the tariff always reduces foreign and world utilities and is a "beggar thy neighbour" policy, though the welfare effects in the short run are ambiguous. This paper asserts that protection is a sub-optimal policy.

In contrast to a perfectly competitive economy of traditional analysis, under monopolistic competition circumstances VERs harm the exporting country. Through negotiations on both countries, home firms sell a smaller output at a higher price at the step of declining average cost. Production inefficiency is associatd with welfare deterioration.

The following proposition summarizes the welfare evaluations of VERs :

Proposition 3: With imperfect competition, a VER always reduces world welfare and hence is never a first-best policy. The assertion that protection is a sub-optimal policy is robust. The adoption of VERs in inter-country negotiations should be imposed meticulously and even ruled out.

\section{Discussions and Conclusions}

This paper proposes an original approach for modelling voluntary export restraints. Instead of using a traditional partial equilibrium framework, it uses a macroeconomic 
sticky-price model extended from Obstfeld and Rogoff (1995). Studying VERs in a macroeconomic framework implies that such trade policy has an economic wide impact. In particular, we provide numerical simulations for evaluating large welfare effects of VERs.

The key features characterizing the macroeconomic and welfare effects of VERs in a small exporting open economy include: (i) the negotiated price undertakings (i.e. a VER sets) and (ii) the presence of imperfect competition in the world goods market. The interaction of (i) and (ii) introduces an important role for the evaluation VERs. Because the exporting country voluntarily sets higher prices, on impact, the exchange rate adjusts upward with the country size of home economy, $n$, and the premium $\gamma$, but adjusts downward with the VERs imposed varieties, $k$. Especially (ii) is associated with spillover effects, which are crucial for the specific characterization of the role of the authorities.

We derive the result that with imperfect competition, in the short run, for the exporting (home) country, VERs has some positive effects on income, consumption, and the current account. By contrast, VERs reduces the income and consumption in the importing (foreign) country. Nevertheless, VERs exerts only transitory expansion effect on domestic macroeconomics. In the long run, the home country experiences the reduction in output and consumption, the current account deficit, and the deterioration of the terms of trade.

Numerical examples quantify welfare effects of VERs and suggest that both country sizes and imperfect competition significantly affect the macroeconomic effects of commercial policy shifts. Analytical results find that with imperfect competition as the case for VERs, the exchange rate is less volatile in the long run than on impact. However, without VERs, this situation is reversed (Obstfeld and Rogoff op. cit., p. 653). In the long run, with flexible output prices, the exporting country experiences the reduction in output and consumption, the current account deficit, and the deterioration of the terms of trade. Especially from the welfare criterion, in the long run, VERs can not affect either the macroeconomy of the importing (foreign) country or the global welfare, and the result contrasts with that of De Santis (2003) but is in line with that of Zhou and Vertinsky (2002).

From the proceeding analyses, this paper has generated a number of results of interest and sheds further light on arguments for and against imposing VERs. In the faithful orthodox model, it is unambiguous that the exporting country stands to gain from the policy switch (from tariffs to VERs), and that the importing country may lose. However, as the model is made more realistic, with imperfect competition, the likelihood for gain by the exporting country decreases or diminishes and that for loss increases. The less competition in the goods market, the less positive effects are on the macroeconomy of the exporting country. Previous literature might not be able to predict long-term adjustments on the welfare losses that VERs impose through distortion to consumption and production efficiency. The theoretical model employed in this paper does not suffer from the general criticism that it is based on the premise of perfect competition.

Voluntary export restraints have become prominent in the trade policies not only because of the practical considerations regarding their falling outside the rules of WTO (World Trade Organization) but also the relative ease with which they can 
be renegotiated, as they often have been. Moreover, importing countries found that the discriminatory nature to be particularly suited to their needs. However, analytical results suggest that, with imperfect competition, VERs should be imposed meticulously and even discontinued or abolished for products and countries.

\section{References}

Anderson, J. E. (1985), "The Relative Inefficiency of Quotas: the Cheese Case." American Economic Review, 75, pp. 178-190.

Aw, B. Y. (1992), "An Empirical Model of Mark-ups in a Quality-differentiated Export Market." Journal of International Economics, 33, pp. 327-344.

Berry, S., Levinsohn, J., Pakes, A. (1999), "Voluntary Export Restraints on Automobiles: Evaluating a Trade Policy." American Economic Review, 89, pp. 400-430.

Bouët, A. (2001), "Research and Development, Voluntary Export Restriction and Tariffs." European Economic Review, 45, pp. 323-336.

Chao, C. C., Yu, E. S. H. (1996), "Product Differentiation, Voluntary Export Restraints, and Profits." Managerial and Decision Economics, 17, pp.103-110.

De Santis, R. A. (2003), "Why Exporting Countries Agree to Voluntary Export Restraints: the Oligopolistic Power of the Foreign Supplier." Scottish Journal of Political Economy, 50: pp. 247-263.

Dei, F. (1985), "Welfare Gains from Capital Inflows under Import Quotas." Economics Letters, 18, pp. 237-240.

Demidova, A., Rodrigues-Clare, A. (2009), "Trade Policy under Firm-level Heterogeneity in a Small Economy." Journal of International Economics, 78, pp. 100-112.

El-Agraa, A. M. (1995), "VERs as a Prominent Feature of Japanese Trade Policy: their Rational, Costs and Benefits." The World Economy, 18, pp. 219-235.

Fender, J., Yip, C. K. (2000), "Tariffs and Exchange Rate Dynamics Redux." Journal of International Money and Finance, 19, pp. 633-655.

Flam, H. (1994), "EC Members Fighting about Surplus: VERs, FDI and Japanese Cars." Journal of International Economics, 36, pp.117-131.

Gandolfo, G. (1998), International Trade Theory and Policy. Springer-Verlag, Berlin.

Hariss, R. (1985), "Why Voluntary Export Restraints Are 'Voluntary'." Canadian Journal of Economics, 18, pp. 799-809.

Jones, L., Manuelli, R., Rossi, P. (1993), "Optimal Taxation in Models of Endogenous Growth.” Journal of Political Economy, 101, pp. 485-513.

Krishna, K. (1989), "Trade Restrictions as Facilitating Practices." Journal of International Economics, 26, pp. 251-270.

Moore, M. O. (2005), "VERs and Price Undertakings under the WTO." Review of International Economics, 13, pp. 298-310.

Moore, M. O., Suranovic, S. M. (1993), "A Welfare Comparison between VERs and Tariffs under the GATT." Canadian Journal of Economics, 26, pp. 447-457.

Obstfeld, M., Rogoff, K. (1995), "Exchange Rate Dynamics Redux." Journal of Political Economy, 103, pp. 624-660.

Ono, Y. (1984), "Profitability of Export Restraints." Journal of International Economics, 16, pp. 335-343.

Okawa, M. (2004), "Voluntary Export Restraints under Imperfect Competition." Review of International Economics, 12, pp. 138-150.

Zhou, D., Vertinsky, I. (2002), "Can Protectionist Trade Measures Make a Country Better off? A study of VERs and minimum quality standards." Journal of Business Research, 55, pp. 227-236. 